\title{
The hungry stomach: physiology, disease, and drug development opportunities
}

\author{
Gareth J. Sanger ${ }^{*}$, Per M. Hellström ${ }^{2}$ and Erik Näslund ${ }^{3}$ \\ 1 Wingate Institute of Neurogastroenterology, Barts and The London School of Medicine and Dentistry, Queen Mary University of London, London, UK \\ 2 Department of Medical Sciences, Uppsala University, Uppsala, Sweden \\ ${ }^{3}$ Division of Surgery, Department of Clinical Sciences, Danderyd Hospital, Karolinska Institutet, Stockholm, Sweden
}

\section{Edited by:}

Pamela J. Hornby, Johnson \& Johnson, USA

\section{Reviewed by:}

Pamela J. Hornby, Johnson \& Johnson, USA

\section{${ }^{*}$ Correspondence:}

Gareth J. Sanger, Wingate Institute of Neurogastroenterology, Barts and The London School of Medicine and

Dentistry, Queen Mary University of London, 26 Ashfield Street, London E1 2AJ, UK.

e-mail:g.sanger@qmul.ac.uk
During hunger, a series of high-amplitude contractions of the stomach and small intestine (phase III), which form part of a cycle of quiescence and contractions (known as the migrating motor complex, MMC), play a "housekeeping" role prior to the next meal, and may contribute toward the development of hunger. Several gastrointestinal (GI) hormones are associated with phase III MMC activity, but currently the most prominent is motilin, thought to at least partly mediate phase III contractions of the gastric MMC. Additional GI endocrine and neuronal systems play even more powerful roles in the development of hunger. In particular, the ghrelin-precursor gene is proving to have a complex physiology, giving rise to three different products: ghrelin itself, which is formed from a post-translational modification of des-acyl-ghrelin, and obestatin. The receptors acted on by des-acyl-ghrelin and by obestatin are currently unknown but both these peptides seem able to exert actions which oppose that of ghrelin, either indirectly or directly. An increased understanding of the actions of these peptides is helping to unravel a number of different eating disorders and providing opportunities for the discovery of new drugs to regulate dysfunctional gastric behaviors and appetite. To date, ghrelin and motilin receptor agonists and antagonists have been described. The most advanced are compounds which activate the ghrelin and motilin receptors which are being progressed for disorders associated with gastric hypomotility.

Keywords: migrating motor complex, motilin, ghrelin, des-acyl-ghrelin, obestatin, stomach

\section{INTRODUCTION}

Read (1992) defined "hunger" as a word usually applied to the sensation of needing food, whereas in humans at least, the word "appetite" also encompasses the desire to eat and the enjoyment of certain foods. Hunger is not abolished by distension of the stomach by a balloon or by infusion of lipids into the bloodstream, but by a nutrient load within the small intestine (Read, 1992). This suggested that mechanisms within the gastrointestinal (GI) tract have the capacity to influence what we eat. A subsequent explosion in understanding how neuronal and hormonal communication from different regions of the GI tract can modulate food intake (Bray, 2000) and energy homeostasis (Murphy and Bloom, 2006) now places the gut, the largest endocrine organ of the body, at the center of an integrated gut-brain-energy axis, in which digestion is coordinated with appetite, satiation, and metabolism. It follows that disruption of this axis can be linked to early or late satiety, nausea, and to several conditions associated with eating and metabolic disorders and/or delayed gastric emptying.

During hunger, the muscle of the stomach and small intestine is largely quiescent. However, a regular cycle of contractions play a "housekeeping" role prior to the next meal and may contribute toward the development of hunger. This cycle of quiescence and contractions is known as the migrating motor complex (MMC), and particular phases of the MMC are closely associated with the release of certain GI hormones. Figure 1 illustrates the peak strength of the contractions which can begin in the middle part of the stomach and are temporally associated with hunger sensations. In addition, other GI endocrine and neuronal systems play even more powerful roles in the development of hunger.

The ways in which appetite can be modulated via mechanisms originating within the brain, have previously been described (Rolls, 1981; Cline et al., 2009). Here we focus on the role of the upper GI tract (and its large compliment of hormones) in the mechanisms of hunger, dividing the discussion into four key areas:

- The movements of the stomach and small intestine during hunger and their relationships with the release of GI hormones which are primarily involved in regulating GI motility, and which also assist in the development of hunger.

- The release of other GI hormones from the stomach during hunger, which although having the potential to affect gastric motility, appear to play greater roles in driving hunger and appetite, operating via GI, vagal, and central nerve mechanisms.

- The dysregulation of these processes during illness.

- The ways in which an understanding of the hungry stomach is leading to the discovery of new drugs to regulate dysfunctional gastric behaviors and appetite. 


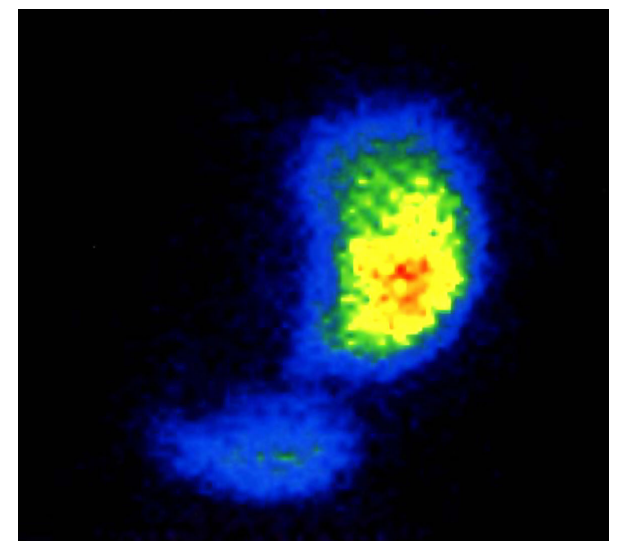

FIGURE 1 | Illustrates the strength of the contractions which begin in the middle part of the stomach and which are temporally associated with hunger sensations (image through courtesy of Per Grybäck).

\section{MOVEMENTS OF THE HUNGRY STOMACH AND SMALL INTESTINE \\ THE MIGRATING MOTOR COMPLEX}

In humans the stomach and small intestine adopt a cyclic pattern of motility and secretion during fasting, first noted in association with hunger by Boldyreff in St Petersburg, Russia, in 1905, and later rediscovered and described as the MMC by Szurszewski (1969) in the canine small intestine. MMCs are usually characterized by a relatively long period of near-quiescence (phase I), followed by a series of short, mostly non-propulsive contractions at irregular frequency (phase II) and then a short burst of high-amplitude propulsive contractions (phase III; Sarna, 1985; Nieuwenhuijs et al., 1998; Husebye, 1999). Figure 2 shows an MMC trace taken from an 8-channel antroduodenal motility recording of a healthy test subject experiencing a hunger pang. In humans the MMC has a cycle time of between 80 and $120 \mathrm{~min}$, during which phase III may last around 5-8 min. MMCs can occur during the day or night (when phase I occupies a greater time at the expense of phase II) and about $60 \%$ of phase IIIs begin in the stomach, the rest beginning at the ligament of Treitz on the border between the duodenum and jejunum (Kellow et al., 1986). MMCs move down the small intestine and its characteristic activity front (phase III) terminates in the distal small intestine. MMC activity is also accompanied by variations in splanchnic blood flow, gall-bladder emptying, and gastric and pancreatic secretions (Thollander et al., 1996; Nieuwenhuijs et al., 1998; Husebye, 1999). Ingestion of a meal replaces MMC activity with a "feeding pattern" of motility (Sarna, 1985).

It is important to note that considerable species differences exist between the characteristics and mechanisms of MMCs. Carnivores such as dogs exhibit MMC activity with characteristics similar to that of humans (Sarna, 1985). Herbivores such as rabbits and rodents (including guinea-pigs, mice, and rats) exhibit different MMC patterns and mechanisms. In rabbits the stomach is never empty and phase III myoelectric activity can be detected even after feeding (Ruckebusch et al., 1985; Guerrero-Lindner et al., 1996). In rats, phase III-like MMC activity occurs at a much faster rate than in humans and dogs (12-15 min compared with 90-100 min; Argia et al., 2007). Further, the clear role of the GI hormone motilin in the mechanisms of phase III MMC activity in the human and dog stomach (see Mechanisms of the MMC, below) and the absence of a functional motilin system in rats and mice (He et al., 2010) indicates that the mechanisms of gastric MMCs in these rodents are very different to those in humans and dogs. Perhaps in rats and mice the functions of motilin are unnecessary or are mimicked by those of ghrelin (Argia et al., 2007). Whatever the explanation, the differences indicate that in terms of human GI functions, the translational value of studies on MMC activity in rodents must be treated with caution. For this reason, this section focuses only on studies which use humans or dogs.

\section{FUNCTIONS OF THE MMC}

Phase III MMC activity is thought to help prevent bacterial overgrowth in the upper gut and clear the stomach and intestine from any undigested material not removed during normal gastric emptying (Vantrappen et al., 1977; Nieuwenhuijs et al., 1998; Husebye, 1999). MMCs may also help create the sensation of hunger. Itoh et al. (1975) first described phase III MMC contractions as "hunger contractions." More recently phase III activity of MMCs which spontaneously originate in the stomach were shown to correlate with the sensation of hunger - a similar correlation was not observed for MMCs originating within the small intestine (Ang et al., 2008a,b). Thus, hunger sensations seem to primarily emanate from the gastric antrum.

\section{MECHANISMS OF THE MMC}

Although phases II and III are mediated via the enteric nervous system (ENS), phase III is initiated via the vagus nerve. Thus in the canine stomach, phase III MMC activity has been prevented or reduced by vagotomy or other procedures which reduce vagal activity (Hall et al., 1984; Tanaka et al., 2001; Shibata et al., 2002). However, the mechanisms which regulate the periodicity of the MMC cycle are regionally specific and are thought to be governed by the local release of 5-HT and motilin from the mucosa of the upper gut.

Nakajima et al. (2010) proposed that MMCs begin with a build-up of 5-HT, released from enterochromaffin cells in the mucosa of the duodenum during phase I. The released 5-HT acts at $5-\mathrm{HT}_{4}$ receptors within the ENS to increase GI motility, representing phase II of the MMC. The mechanical activity caused by the increased motility is then argued to release more 5-HT from the enterochromaffin cells, which initiates phase III by activating $5-\mathrm{HT}_{4}$ receptors in the intestine and $5-\mathrm{HT}_{3}$ receptors in the stomach. Thus, phase III MMC activity can be attenuated by $5-\mathrm{HT}_{3}$ receptor antagonism when the MMC originates in the stomach (Yoshida et al., 1991; Wilmer et al., 1993; Nakajima et al., 2010) but not clearly in the intestine (Davidson et al., 1990). Instead, 5- $\mathrm{HT}_{4}$ receptor antagonism was found to inhibit phase II and III MMC activity in the canine small intestine, a procedure which was similarly effective in the stomach (Nakajima et al., 2010).

The increased contractions also increase the release of motilin from endocrine cells in the mucosa to induce or re-enforce gastric phase III MMC activity (Sarna, 1985; Peeters, 1993). Thus, although the release of motilin is not prevented by vagotomy (Yoshiya et al., 1985) or by $5-\mathrm{HT}_{3}$ receptor antagonism (Yoshida et al., 1991), 


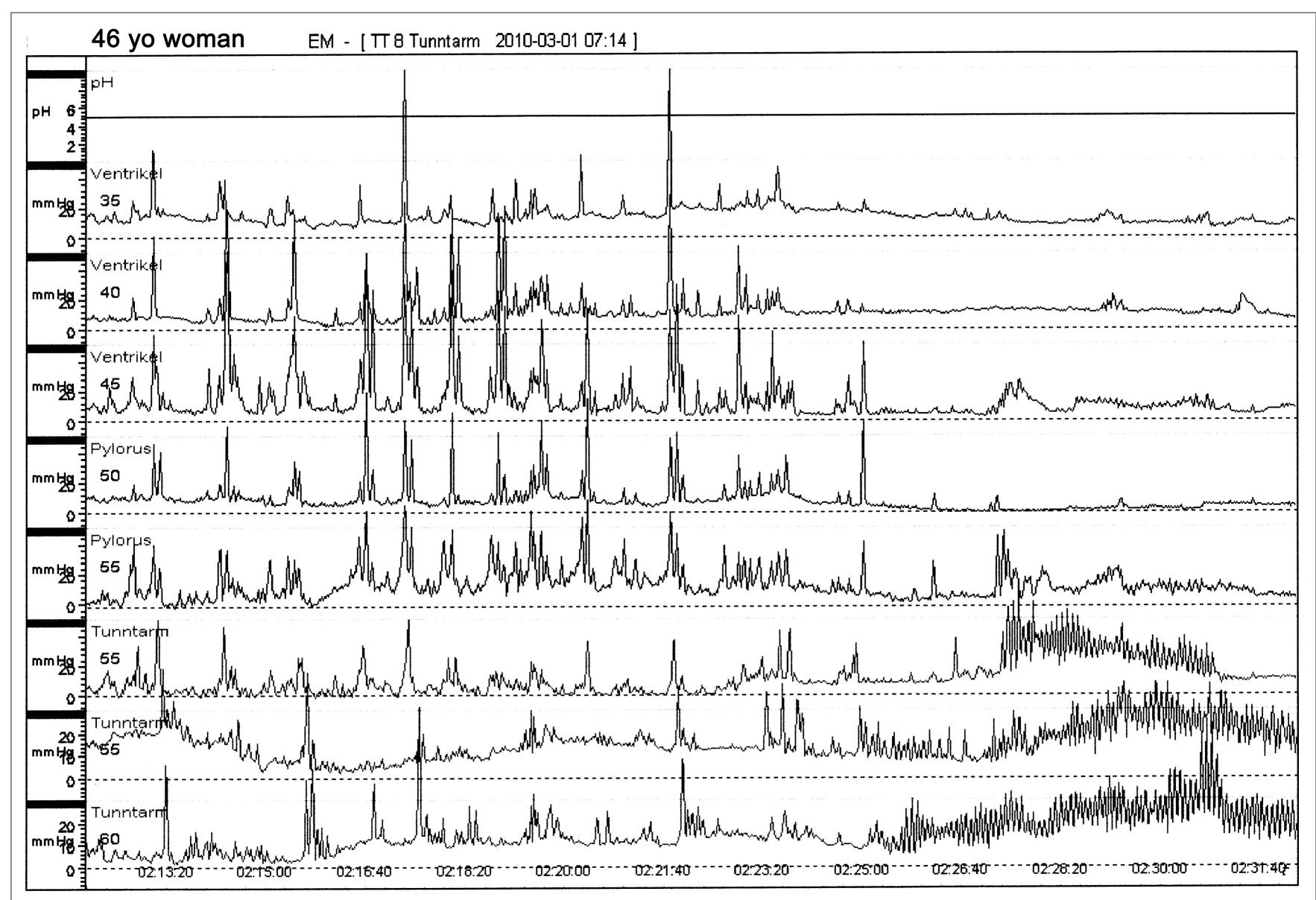

FIGURE 2 | Propagated phase III from antrum through jejunum, preceded by phase II and followed by phase I, of the migrating motor complex of a healthy subject experiencing hunger.

phase III MMC activity within the stomach can be attenuated by motilin antiserum (Lee et al., 1983). Motilin acts by strongly facilitating gastric cholinergic motor nerve activity in a short-lasting manner (Dass et al., 2003a; Jarvie et al., 2007), consistent with its role in mediating the short-lived phase III contractions. The released motilin may also activate the vagus nerve. This has been demonstrated in conscious dogs, where motilin evoked a transient increase in blood plasma concentrations of pancreatic polypeptide (Mochiki et al., 1997) and insulin (Suzuki et al., 1998) via vagal muscarinic pathways; these effects are consistent with the increase in plasma concentrations of both hormones in association with phase III gastric MMC activity (Suzuki et al., 1998). Acute vagal blockade has also been reported to inhibit the increase in canine gastric motility caused by low but not by high doses of motilin (Inatomi et al., 1996). Interestingly, induction of a gastric phase III-like activity by administration of the motilin receptor agonist erythromycin was recently shown to correlate with the sensation of hunger (Ang et al., 2008a,b). These observations reinforce the suggestion of a role for motilin, released in association with phase III of the gastric MMC, to promote hunger either directly (e.g., by activating the vagus nerve) or indirectly by promoting the release of ghrelin (Zietlow et al., 2010; see below for discussion on the role of ghrelin in hunger).
The reasons why both 5-HT and motilin are involved in regulating the mechanisms which support phase III MMC activity are not clear.

\section{ASSOCIATIONS BETWEEN MMCs AND THE RELEASE OF OTHER GI HORMONES}

In addition to motilin, other peptides are associated with phase III MMC activity. One of the most recently studied is ghrelin, a 28-amino acid peptide first derived from rat stomach and shown to be the natural ligand for the growth hormone (GH) secretagogue receptor 1a (Kojima et al., 1999), now renamed as the ghrelin receptor (Davenport et al., 2005). Ghrelin has several actions, among which are the ability to release GH and other hormones into the circulation, stimulate appetite, and modulate fat utilization (Williams and Cummings, 2005; Huda, et al., 2006; Murphy and Bloom, 2006). In humans ghrelin can increase the rate of gastric emptying (e.g., Levin et al., 2006) via vagal nerve activation (Asakawa et al., 2001; Date et al., 2002; Sakata et al., 2003) and to a lesser extent via receptors within the ENS (Dass et al., 2003b; Edholm et al., 2004). This prokinetic activity may even induce a premature phase III of the MMC (Tack et al., 2006). Nevertheless, the gastric prokinetic properties of ghrelin are usually apparent only when high blood concentrations of ghrelin are achieved by the use of exogenously 
administered ghrelin or ghrelin receptor agonists (Camilleri et al., 2009). Further, there have been no studies demonstrating a cyclical release of ghrelin which coincides with the phases of the MMC. Instead, ghrelin levels display a diurnal rhythm in humans, with a peak at night during fasting, and lowest concentrations in the morning after breakfast (Cummings et al., 2001). It is, therefore, unlikely that ghrelin is involved in the physiological regulation of MMCs in man.

It has been reported that increases in blood concentrations of somatostatin occur in association with phase III MMC activity originating in the stomach and duodenum (Peeters et al., 1983; Chung et al., 1995; Tomita, 2009) although this was not found in two other studies where duodenal MMCs were recorded (Näslund et al., 1998; Medhus et al., 1999); nevertheless, increased duodenal intraluminal concentrations were observed (Näslund et al., 1998). The exact role of the released somatostatin is not clear, since intravenousadministration of somatostatin or the somatostatin SST2 receptor agonist octreotide may abolish all activity within the stomach, delay small intestinal transit and inhibit intestinal phase II activity while initiating phase III-like activity (Peeters et al., 1983; Von der Ohe et al., 1995). In addition to somatostatin, peak intraduodenal levels of VIP and substance $P$ have also been associated with human duodenal phase III activity (Näslund et al., 1998), suggesting an ability of certain neuropeptides to modulate GI functions during this phase of the MMC, after diffusion into local neurocircuits. Increases in blood concentrations of xenin (found in specific endocrine cells of duodenal mucosa) have also been found in association with phase III MMC activity and when given IV initiate phase III-like activity in intestine (Feurle et al., 2001). Finally, relationships between MMC activity and blood plasma concentrations of other gut hormones such as gastrin, glucagon, gastric inhibitory polypeptide (Rees et al., 1982), vasoactive intestinal peptide, or substance $P$, have not been found (Näslund et al., 1998).

\section{GI HORMONES, HUNGER, AND APPETITE}

Fasting decreases the availability of hormones such as leptin and glucagon-like peptide-1, which are released from the gut after eating meals to reduce appetite and help control the flow of nutrients down the GI tract (Näslund and Hellström, 2007). However the availability of other GI hormones is increased. In addition to motilin these include ghrelin and orexin, which are not released in close association with MMC activity, but can influence hunger and metabolism.

\section{PRODUCTS OF THE PREPROGENE GHRELIN GENE}

This extraordinary gene generates three different peptides, desacyl-ghrelin, ghrelin, and obestatin, which may each have their own functions but which also interact to regulate the functions of ghrelin. Each is described separately.

\section{Ghrelin}

The release of this hormone from endocrine cells within the stomach (where the largest amounts are found) increases plasma ghrelin concentrations in humans during fasting. The fact that plasma concentrations rise just before mealtimes and drop after eating, prompted Cummings et al. (2001) to suggest a role for ghrelin in meal initiation. Later studies showing that the magnitude of suppression of ghrelin release may be dependent on the type of food (the rank order for suppression was protein > carbohydrate $>$ lipid) suggests a finer control than previously appreciated (Foster-Schubert and Cummings, 2006). The released ghrelin may promote appetite in humans by activation of vagal nerve pathways (le Roux et al., 2005) or after release into the blood and transport across the blood-brain barrier to act centrally (though active transport systems also exist to remove ghrelin from the brain; Banks et al., 2002). Interestingly, the sensitivity of ghrelin receptors may be increased during fasting (Scott et al., 2007). Further, an ability of ghrelin to inhibit emesis (Rudd et al., 2006), prompts the idea that appetite and nausea are opposite ends of the same pathway, so that hormones such as ghrelin which increase appetite also reduce nausea, and vice versa (Sanger and Lee, 2008). This activity of ghrelin may contribute to the reduction in vomiting observed in patients with diabetic gastroparesis following intravenous-administration of the ghrelin receptor agonist TZP-101 (Wo et al., 2010). Also, the orally active compound TZP-102 is reported to improve symptoms within 1 week of treatment initiation with significant reductions in symptom scores for nausea, early satiety, excessive fullness, postprandial fullness, and the total Gastroparesis Cardinal Symptom Index. In addition, improvement of upper and lower abdominal pain and discomfort has been noted ${ }^{1}$ (Presentation by John Wo at ACG 2010, October 20, 2010).

\section{Des-acyl-ghrelin}

Ghrelin is formed from the non-acylated peptide (des-acyl-ghrelin) by a unique post-translational acylation of the third serine residue. This modification is mediated by ghrelin $O$-acyl transferase (GOAT) and can be readily reversed by endogenous esterases (Gutierrez et al., 2008). GOAT is primarily localized to the stomach and intestine, tissues from which active ghrelin is secreted (Yang et al., 2008). Since acylation may be at least partly regulated by nutrient availability in the gut (Liu et al., 2008), it is becoming clear that the ratio of ghrelin to des-acyl-ghrelin may be under physiological and/or pathological control. Such control may be important in tissues where des-acyl-ghrelin has biological activity.

In blood plasma from healthy volunteers the concentration of des-acyl-ghrelin greatly exceeds that of acylated ghrelin (Chen et al., 2009) and an ability of this peptide to affect GI function is increasingly recognized (Fujimiya et al., 2010). For example, in rats, intraperitoneal administration of des-acyl-ghrelin decreased food intake in free-feeding rats during the dark, but not the light phase of food intake (Chen et al., 2005). However, in another example, systemically administered des-acyl-ghrelin did not affect appetite in rats and mice but stimulated feeding when administered via the intracerebroventricular route, an activity also present in ghrelin receptor knock-out mice (Toshinai et al., 2006). These data contribute to the hypothesis that des-acyl-ghrelin can act via binding sites that are distinct from the ghrelin receptor (Lear et al., 2010). Finally, central and systemic administration of desacyl-ghrelin may also disrupt fasted but not fed motility in the gastric antrum, an activity apparently dependent on activation of $\mathrm{CRF}_{2}$ receptors in the brain (after the peptide had crossed the

${ }^{1}$ http://www.news-medical.net/news/20100629/Tranzyme-reports-positive-resultsfrom-TZP-102-Phase-2-study-in-diabetic-patients-with-gastroparesis.aspx 
blood-brain barrier) but curiously, not on vagal nerve activity (Chen et al., 2005). Together, these data indicate a need to further explore the GI roles of des-acyl-ghrelin.

\section{Obestatin}

This peptide was identified through sequence analysis of the ghrelinprecursor gene, proghrelin (Zhang et al., 2005). Initially, obestatin was thought to be the endogenous ligand for the orphan $G$ proteincoupled receptor GPR39, and when systemically administered was shown to suppress feeding and weight gain in mice in a time- and dose-dependent manner, as well as reduce rat gastric emptying (Zhang et al., 2005). Unfortunately the proposal that obestatin represented the endogenous ligand for GPR39 is no longer accepted (Wigglesworth et al., 2006; Holst et al., 2007; Zhang et al., 2007). Nevertheless, the ability of obestatin to inhibit food intake has been replicated (Zhang et al., 2007) and confirmed or partly confirmed (Bresciani et al., 2006; Sibilia et al., 2006; Lagaud et al., 2007; Chen et al., 2009), although not when administered centrally (albeit using a different protocol; Seoane et al., 2006). However, it is worth noting that although obestatin was shown to have a considerable effect on food intake, there was no actual reduction in body weight but rather a slower weight gain; changes in fat mass were not measured (Zhang et al., 2005). Another study suggests that obestatin may increase thirst (Samson et al., 2007). Finally, serum leptin levels were not affected by either ghrelin (Zhang et al., 2005; Falkén et al., 2010) or obestatin (Zhang et al., 2005), suggesting that both these effects were outside of adipose tissue and most likely confined to the GI tract (Nogueiras and Tschöp, 2005).

Several studies have failed to demonstrate significant effects of obestatin on GI motility when using in vitro models, when measuring MMC activity or gastric emptying of a non-nutrient meal (Gourcerol et al., 2006; Bassil et al., 2007; De Smet et al., 2007). Ataka et al. (2008) confirmed these observations but then showed that the gastro-duodenal motility of rats after eating standard chow was inhibited 30-90 min after intravenous-administration of obestatin. This inhibitory action appeared to be dependent on $\mathrm{CRF}_{1}$ and $\mathrm{CRF}_{2}$ receptor activity within the brain, and for the duodenum but not the antrum, was also prevented by capsaicin pretreatment. From these and other data, the authors suggested that obestatin acts centrally (after crossing the blood-brain barrier) and at the vagus, to inhibit rat upper GI motility, but only after feeding (Ataka et al., 2008; Fujimiya et al., 2010).

The studies with obestatin and GPR39 raise important questions. Firstly, since obestatin has undoubted biological activity and since immunoreactivity for obestatin has been detected in the rat gastric mucosa and in myenteric plexus (Dun et al., 2006), what is the role of this source of obestatin and what receptor does it act on? One possibility is suggested by the fact that obestatin appears to act in a manner which is opposite to that of ghrelin - reducing appetite and gastric emptying after meals, and antagonizing certain functions of ghrelin (Zhang et al., 2005; Bassil et al., 2007; Fujimiya et al., 2010; Kumar et al., 2010). Such activity points toward a role in the mechanisms of nausea, contrasting to the anti-emetic activity of ghrelin (Rudd et al., 2006). Another question is created by reports that GPR39 is upregulated in rat adipose tissue during fasting (Egerød et al., 2007) and that mice lacking GPR39 appear to have normal food intake and body weight gain (Tremblay et al., 2007) but increased gastric emptying (Moechars et al., 2006) and a changed glucose-dependent insulin secretion (Tremblay et al., 2009). Do these observations suggest that the cognate ligand for GPR39 will have profound effects on GI functions? Clues may be provided by the suggestion that GPR39 is the receptor which mediates the ability of free zinc ions $\left(\mathrm{Zn}^{2+}\right)$ to affect cell functions (Egerød et al., 2007). GPR39 receptors are found throughout the GI tract (Egerød et al., 2007; Yamamoto et al., 2009) raising the possibility that these receptors mediate the ability of $\mathrm{Zn}^{2+}$ to modulate colonocyte functions such as proliferation, ion transport, and hormone transport, reduce epithelial erosion and inhibit diarrhea (Azriel-Tamir et al., 2004; Hershfinkel et al., 2007; Sharir et al., 2010). A role for $\mathrm{Zn}^{2+}$ sensitive receptors in upper GI functions is not clear but now needs to be investigated.

\section{OREXIN}

Plasma concentrations of orexin also increase during fasting (Komaki et al., 2001). This hormone, present as orexin A and $\mathrm{B}$ in the myenteric plexus and endocrine cells of the human GI tract (and pancreas; Nakabayashi et al., 2003) has been reported to depolarize enteric neurons and facilitate gastric nitrergic activity in rodents (Katayama et al., 2005; Baccari et al., 2009), inhibit rat small intestinal MMC activity, stimulate rat gastric emptying and increase acid secretion (Näslund et al., 2002; Bülbül et al., 2010). However, in healthy human volunteers, infusion of orexin caused only a small inhibition of gastric emptying and failed to affect appetite (Ehrström et al., 2005), suggesting that the release of orexin from endocrine cells of the gut during fasting may play only a minor role in the control of human gastric emptying during hunger. Instead, the decrease in plasma concentrations of leptin and increase in insulin suggest a possible role in metabolic regulation (Ehrström et al., 2005).

\section{DYSREGULATION OF THE HUNGRY HUMAN STOMACH GASTROINTESTINAL MOTILITY}

Disorders associated with disrupted MMC activity are not common, although clearly MMCs are absent during the paralytic ileus which follows abdominal and other types of surgery. MMCs reoccur in the proximal small intestine within $3 \mathrm{~h}$ after the surgery but initially with a quicker cycle time and reduced Phase II activity (Benson et al., 1994; Husebye, 1999). Interesting, patients undergoing gastrectomy for gastric cancer who then had Roux-en-Y reconstruction (the stomach is removed and to achieve continuity to the intestine the proximal jejunum is divided and the aboral jejunum anastomosed to the esophagus - the divided oral part of the jejunum is reconnected to the jejunum distal to the esophageal anastomosis so bile and pancreatic secretions can be directed into the jejunum and the shape of a Y is created), could be divided into those with intestinal MMC activity and those without (Tomita et al., 2003). Compared to the latter, patients with phase III MMC activity tended to have more appetite and greater food intake, as well as fewer symptoms associated with dumping, reflux, nausea or lower bowel symptoms. These observations show the importance of the MMC activity in eliciting hunger sensations.

Vantrappen et al. (1977) hypothesized that a dysfunctional MMC would lead to bacterial overgrowth within the upper gut, in an environment favored by accumulation of food remnants, 
desquamated cells, and secretions. Such patients were detected using a ${ }^{14} \mathrm{CO}_{2}$ bile acid breath test and treated successfully with antibiotic drugs. The number of patients studied were, however, too small to speculate on the causes of the dysfunctional MMC.

Phase III-like activity persists in mechanically ventilated patients with critical illness, following perfusion of the small intestine with liquid nutrients (Chapman et al., 2005). Plasma motilin concentrations may be increased during such infusions, rather than decreased as in healthy volunteers (Nguyen et al., 2010). The reasons for these differences are not clear.

Migrating motor complex activity has often been studied in patients with functional bowel disorders, especially irritable bowel syndrome. Small variations have been observed, critically discussed by Husebye (1999). The role of any changes in the etiology of the disorders is, however, far from clear, being most likely caused by the disorder itself. Perhaps the most interesting are a group of patients with an idiopathic delay in gastric emptying where MMC activity was reduced or absent (Labò et al., 1990).

Finally, although not a disorder of hunger itself, gastric phase III MMC activity may lead to increased gastro-esophageal reflux during the night (Gill et al., 1987). This activity, observed in healthy individuals, has clear consequences for patients with hiatus hernia.

\section{HORMONAL STATUS}

There are physiological and pathological conditions characterized by high circulating ghrelin levels. These include starvation, anorexia nervosa (Otto et al., 2001), bulimia (Tanaka et al., 2002), and cachexia (Nagaya et al., 2001), in which ghrelin values are doubled, compared with normal controls. Binge eating has been associated with a dysfunction in the ghrelin signaling system and with a reduction in post-prandial satiety cues arising from an increase in gastric capacity (Hellström et al., 2004).

In patients with anorexia nervosa, plasma concentrations of ghrelin are paradoxically higher (Nakai et al., 2003) but return to normal as patients increase in weight; it has been demonstrated that there is a specific reduction in the $\mathrm{GH}$ response to ghrelin, despite the hyper-responsiveness to administration of $\mathrm{GH}$ releasing hormone. The impaired GH response to ghrelin could reflect desensitization of the ghrelin receptor induced by chronic elevation of ghrelin levels in this pathological state (Broglio et al., 2004). Interestingly there is one report of a patient with a ghrelin-producing neuroendocrine tumor who had circulating plasma concentrations of ghrelin of $12000 \mathrm{pM}$. There is no report regarding hunger sensations in this patient but she was obese (BMI $29.9 \mathrm{~kg} / \mathrm{m}^{2}$ ) and had type 2 diabetes mellitus (Corbetta et al., 2003).

Clinical conditions associated with changes in blood concentrations of des-acyl-ghrelin and obestatin are as yet, unclear. Nevertheless, important biological functions are suggested by close links between ghrelin and obestatin (both are co-produced and their ligand and receptor sequences are highly conserved throughout mammalian evolution, along with the functions; Kaiya et al., 2008) and ghrelin and des-acyl-ghrelin (Kumar et al., 2010). The effects of these peptides now need to be studied in man, especially in patients with obesity and/or nausea.

\section{TRANSLATION TO DRUGS}

Increased understanding of the different roles played by hormones released from the gut during fasting has provided new opportunities for the development of new drugs. To date, motilin and ghrelin are the hormones which have received the most attention.

\section{MOTILIN RECEPTOR ANTAGONISTS}

Recent progress in identification of selective antagonists has been described by Westaway and Sanger (2009). Oral dosing of the motilin receptor antagonist MA-2029 to rabbits reduced motilininduced colonic contractions (Sudo et al., 2008). MA-2029 also reduced abdominal muscle contractions induced by administration of motilin in combination with colorectal distension, indicating a reduction in the visceral pain experienced by these animals that had been exacerbated by motilin (Sudo et al., 2008). Similarly, MA-2029 inhibited motilin-induced increases in gastric fundus tone, GI transit, and diarrhea in conscious dogs without effects on basal GI tone or motility (Ozaki et al., 2009). However, although these experiments demonstrate the pharmacodynamic characteristics of MA-2029 (i.e., they establish that the antagonist can block the effects of exogenously administered motilin in vivo) they do not demonstrate a pathophysiological role for motilin. Evidence for such a role is provided by the macrocyclic peptidomimetic and motilin receptor antagonist TZP201 , which reduced the incidence of diarrhea in a dog model of chemotherapy-induced diarrhea providing a superior level of efficacy compared to loperamide and octreotide (Thomas et al., 2007). If confirmed, these data represent an important breakthrough in establishing a potential therapeutic use for motilin receptor antagonists. TZP-201 was also shown to antagonize motilin-induced contractile activity of the colon of the musk shrew (Venkova et al., 2009a). Although this is again a simple pharmacodynamic study, it is nevertheless, an important observation because these animals represent a small laboratory animal that actually possesses a functional motilin receptor.

\section{MOTILIN RECEPTOR AGONISTS}

In addition to its antibiotic use, erythromycin is used clinically as a gastric prokinetic agent. The latter has been described for a number of different disorders associated with delayed gastric emptying (Sanger, 2008), including patients in critical care receiving enteral feeding (given via a naso-gastric tube; enhanced gastric emptying improves delivery of nutrients, reduces the time needed for intubation, and the incidence of complications such as pulmonary aspiration or infection, improving survival), diabetic patients needing better control of blood glucose, and patients with diabeticor non-diabetic gastroparesis where improved gastric emptying can reduce symptoms. Nevertheless, the ability of erythromycin to inhibit the cytochrome P450 enzyme CYP3A4 and cause drugdrug interactions (Zhou et al., 2004), together with the use of erythromycin as a gastric prokinetic agent in an age when antibiotic resistance continues to rise, highlights the pressing need for alternative medication. The use of erythromycin also highlights the extraordinary lack of safe and effective gastroprokinetic drugs (Sanger and Alpers, 2008). An improved, selective motilin receptor agonist would, therefore, have potential use in each of the conditions described above. A role for motilin receptor agonists in 
reducing post-operative ileus is also suggested by the involvement of motilin in phase III of the gastric MMC, the return of which is used a marker of recovery.

At first, the clinical efficacy of erythromycin as a prokinetic agent may seem surprising in view of the short-lived action of motilin itself; indeed tolerance to repeat-dose erythromycin has been observed (Richards et al., 1993; see below). To understand these apparently conflicting observations, Dass et al. (2003a) and Jarvie et al. (2007) conducted a series of experiments with rabbit isolated stomach, in which the pharmacology of motilin receptor agonists were examined for their abilities to facilitate cholinergically mediated contractions evoked by electrical field stimulation. This model is argued to provide a more physiological representation of their abilities to facilitate on-going gastric emptying (in which the ENS plays a key role), than alternative models which simply investigate their effects on resting muscle tension. Using this technique, low concentrations of motilin were found to greatly facilitate cholinergic activity but in a short-lived manner, consistent with a role for motilin in the short-lasting gastric phase III MMC activity. However, low concentrations of erythromycin induced long-lasting increases in cholinergic activity which did not rapidly fade; higher concentrations of erythromycin evoked greater but shorter-lived responses and also increased muscle tension. Similar observations have now been made using human isolated stomach in which contractions were evoked by electrical field stimulation (Broad et al., 2010). Together, these observations are consistent with the finding that low doses of erythromycin (50-100 mg $3 \times$ daily and at bedtime) reduced symptoms in patients with gastroparesis (Dhir and Richter, 2004) whereas higher doses may tolerate with repeat dosing (250-400 mg 4× daily; Richards et al., 1993). Similarly, symptoms associated with gastroparesis may be improved by repeated intravenous-administration of erythromycin, provided the dose was titrated to achieve efficacy and tolerance in each patient (Dibaise and Quigley, 1999). Further, in human volunteers, a low dose of erythromycin (40 mg) evoked an increase in gastric propulsive activity which could be prevented by atropine (Coulie et al., 1998), whereas a higher dose (200 mg) evoked atropine-resistant, non-propulsive contractions (Coulie et al., 1998) and an increase in meal-induced satiety (Cuomo et al., 2006). Thus, low doses of erythromycin appear to behave in a manner which differs from that of motilin or high doses of erythromycin. The explanation is not clear and speculation centers on possible different binding sites for the peptide and non-peptide structures (Matsuura et al., 2006). The isolated tissue results are also consistent with observations that repeat dosing with low doses of erythromycin may increase gastric emptying whereas higher doses can induce nausea and stomach cramping (Boivin et al., 2003).

The experiments described above argue that it is possible to identify alternative molecules which mimic the actions of erythromycin but in a more selective manner, without the antibiotic activity or ability to inhibit P450 activity. Until recently, these molecules were based on the complex macrolide structure of erythromycin, where small changes in structure removed antibiotic activity but additional changes to optimize the "drug-like" properties of the molecule in an iterative manner are extremely difficult; to date, most have not progressed far in the clinic (Westaway and Sanger, 2009). Table 1 lists the motilin receptor agonists recently described.
The most advanced is mitemcinal, the remaining macrolide still in clinical development (Takanashi and Cynshi, 2009), which has shown some ability to improve symptoms in a subset of patients with diabetic gastroparesis, good glycemic control and a body mass index of $<35 \mathrm{~kg} / \mathrm{m}^{2}$ (McCallum et al., 2007). Interestingly, attempts to profile the desensitization liability of mitemcinal in vitro illustrate the fact that several assays commonly used to examine the functions of motilin in vitro, actually lack translational value. For example, the abilities of mitemcinal and other motilin receptor agonists to cause contraction of rabbit isolated duodenal muscle were reported to undergo rapid tachyphylaxis (Carreras et al., 2004). A desensitization liability was also noted using CHO cells expressing the human motilin receptor (Takanashi and Cynshi, 2009). By contrast, in human volunteers, the ability of mitemcinal to increase gastric emptying was maintained over a 28-day repeatdose schedule (McCallum et al., 2007). This anomaly led to the suggestion (Sanger, 2008; Westaway and Sanger, 2009) that more meaningful in vitro assay was to examine the abilities of motilin receptor agonists to facilitate on-going gastric neuronal activity, argued to represent a more physiological model of gastric motility. Using this model, GSK962040, the most advanced non-motilide small molecule motilin receptor agonist, has been shown to act in a manner similar to that of erythromycin, facilitating cholinergic contractile activity in rabbit (Sanger et al., 2009) and human (Broad et al., 2010) isolated stomach, in a prolonged manner. GSK962040 is currently being evaluated in healthy volunteers, where both singly administered (Dukes et al., 2009) repeated doses (Dukes et al., 2010) accelerated gastric emptying in a maintained manner.

Finally, RQ-00201894 has been described as a non-motilide, small molecule, potent, and selective motilin receptor agonist. However, its structure is currently unknown. This molecule is said to increase gastric emptying in dogs and monkeys, as well as induce gastric Phase III-like activity in dogs (Takahashi et al., 2010).

\section{GHRELIN RECEPTOR ANTAGONISTS}

The use of ghrelin-specific antibodies, immunization against endogenous ghrelin, "RNA Spiegelmers" such as 1-NOX-B11 (oligonucleotides made stable by placing unnatural L-enantiomers of ribose in the sugar-phosphate backbone) and even a vaccine has shown that in adult animals (usually rodents), inhibition of ongoing ghrelin function can reduce food intake and body weight (Foster-Schubert and Cummings, 2006; Zorrilla et al., 2006; Becskei et al., 2008; Depoortere, 2009). These data indicate the potential value of a small molecule ghrelin receptor antagonist (Moulin et al., 2007). Several have been shown to be active against the receptor that is naturally expressed (e.g., in rat isolated pituitary cells) and some have demonstrated an ability to reduce food intake and body weight in rodents as well as improve glucose tolerance (e.g., Esler et al., 2007, who used mice for the feeding experiments and rats for the glucose tolerance test). However, as yet, none have progressed into the clinic.

\section{GHRELIN RECEPTOR AGONISTS}

The multiple activities of ghrelin make this an interesting drug target. Its ability to increase appetite suggests a role in treatment of cachectic patients (Ashitani et al., 2009), as exemplified by 
Table 1 | Motilin and ghrelin receptor agonists under development for the treatment of GI disorders.

$\begin{array}{ll}\text { Compound } & \text { Status } \\ \text { MOTILIN RECEPTOR AGONISTS } & \text { Phase II; diabetic gastroparesis } \\ \text { Mitemcinal (GM-611) } & \text { Preclinical } \\ \text { RSK-00201894 } & \text { Phase I }\end{array}$

\section{GHRELIN RECEPTOR AGONISTS}

Ulimorelin (TZP-101)

TZP-102

Ipamorelin
Entering phase III as IV formulation for GI dysmotility conditions in acute care

Phase II for gastroparesis

Phase II; for opioid-induced bowel dysfunction
EX-1314 (previously known as BMS-604992)

ST-1141
Preclinical

Phase I; for opioid-induced bowel dysfunction

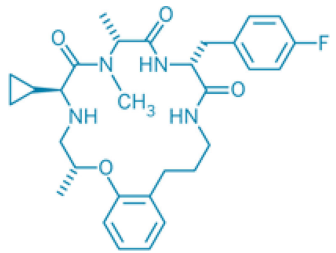

Orally active macrocyclic peptidomimetic

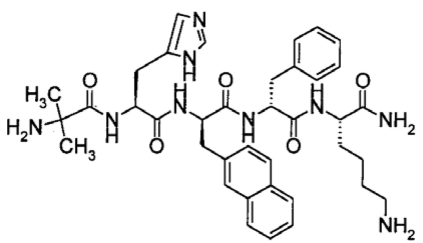

dimethyl glycyl-O-benzyl-serine

.

studies in cancer patients with impaired appetite where ghrelin increased energy intake and meal appreciation during a buffet meal (Neary et al., 2004). The ability of ghrelin to increase gastric emptying also suggests a role in treatment of disorders associated with delayed gastric emptying, as exemplified by animal models of post-operative gastric ileus (Trudel et al., 2003) or septic ileus (De Winter et al., 2004). Finally, an anti-emetic activity of ghrelin (Rudd et al., 2006), combined with the ability to increase appetite and gastric emptying suggests a potential to treat more complex conditions such as dyspepsia, as exemplified in an animal model of this condition (Liu et al., 2006) and as suggested by raised plasma ghrelin levels in patients with functional dyspepsia (Nishizawa et al., 2006).

Table 1 lists the ghrelin receptor agonists being evaluated for a GI disorder. In general, these compounds were first characterized using recombinant receptors, followed by studies in vivo, where their ability to increase gastric emptying and stimulate feeding may be dependent on vagal nerve activity (Page et al., 2007; Sanger 2008). Success in the development of such an agent may lie in selecting a patient group where the new drug is only required on an acute basis (e.g., post-operative ileus), as a potential difficulty with a long-term exposure is the widespread ability of ghrelin to increase endocrine release (Leite-Moreira and Soares, 2007). The need for this caution is exemplified by a study which shows that constant intravenous infusion of ghrelin may provoke a fall in insulin sensitivity (Vestergaard et al., 2007).

Currently the most advanced is TZP-101 (ulimorelin), an intravenously administered macrocyclic peptidomimetic (Fraser et al., 2005) reported to improve GI recovery in patients with post-operative ileus after abdominal surgery (Popescu et al., 2009) and improve symptoms (loss of appetite, vomiting, post-prandial fullness) 4 days after treatment in patients with diabetic gastroparesis (Wo et al., 2010). A second molecule, TZP-102, is said to be orally available and have gastric prokinetic properties ${ }^{2}$, but details have not been published 
for critical review. Ipamorelin, a pentapeptide originally identified as a GH secretagogue (Raun et al., 1998) has been shown to be effective in a rat model of post-operative ileus when given by intravenous infusion (Venkova et al., 2009b). Other molecules include EX-1314, a GI prokinetic able to stimulate food intake in rodents (Charoenthongtrakul et al., 2009) and ST-1141, said to be an orally active for treatment of opioid-induced bowel dysfunction ${ }^{3}$.

\section{CONCLUSIONS}

Recognition that the GI tract represents the largest endocrine organ in the body provides a wealth of opportunities for understanding the physiological control of GI functions and its pathophysiology. Not surprisingly, this increased understanding also creates new opportunities for drug discovery.

${ }^{2} \mathrm{http}: / /$ www.tranzyme.com/pipeline.html

${ }^{3}$ http://www.helsinn.com/

\section{REFERENCES}

Ang, D. C., Nicolai, H., Vos, R., Berghe, P. V., Sifrim, D., Depoortere, I., Peeters, T. L., Janssens, J., and Tack, J. F. (2008a). Hunger scores correlate with the occurrence of pharmacologically induced gastric phase 3 in man. Gastroenterology 134(Suppl. 1), A-285.

Ang, D. C., Nicolai, H., Vos, R., Berghe, P. V., Sifrim, D., Depoortere, I., Peeters, T. L., Janssens, J., and Tack, J. F. (2008b). Gastric phase 3 is a hunger signal in the interdigestive state in man. Gastroenterology 134(Suppl. 1), A-314.

Argia, H., Tsukamoto, K., Chen, C., Mantyh, C., Pappas, T. N., and Takahashi, T. (2007). Endogenous acyl ghrelin is involved in mediating spontaneous phase III-like contractions of the rat stomach. Neurogastroenterol. Motil. 19, 675-680.

Asakawa, A., Inui, A., Kaga, T., Yuzuriha, H., Nagata, T., Ueno, N., Makino, S., Fujimiya, M., Niijima, A., Fujino, M. A., and Kasuga, M. (2001). Ghrelin is an appetite-stimulatory signal from stomach with structural resemblance to motilin. Gastroenterology 120 , 337-345.

Ashitani, J.-I., Matsumoto, N., and Nakazato, M. (2009). Ghrelin and its therapeutic potential for cachectic patients. Peptides 30, 1951-1956.

Ataka, K., Inui, A., Asakawa, A., Kato, I., and Fujimiya, M. (2008). Obestatin inhibits motor activity in the antrum and duodenum in the fed state of conscious rats. Am. J. Physiol. 294, G1210-G1218.

Azriel-Tamir, H., Sharir, H., Schwartz, B., and Hershfinkel, M. (2004). Extracellular zinc triggers ERKdependent activation of $\mathrm{Na}+/ \mathrm{H}+$ exchange in colonocytes mediated by the zinc-sensing receptor. J. Biol. Chem. 279, 51804-51816.

Baccari, M. C., Bani, D., and Calamai, F (2009). Evidence for a modulatory role of orexin A on the nitrergic neurotransmission in the mouse gastric fundus. Regul. Pept. 154, 54-59.

Banks, W.A., Tschöp, M., Robinson, S. M., and Heiman, M. L. (2002). Extent and direction of ghrelin transport across the blood brain barrier is determined by its unique primary structure. $J$. Pharmacol. Exp. Ther. 302, 822-827.

Bassil, A. K., Häglund, Y., Brown, J., Rudholm, T., Hellström, P. M., Näslund, E., Lee, K., and Sanger, G. J. (2007). Little or no ability of obestatin to interact with ghrelin or modify motility in the rat gastrointestinal tract. Br. J. Pharmacol. 150, 58-64.

Becskei, C., Bilik, K. U., Klussmann, S., Jarosch, F., Lutz, T. A., and Riediger, T. (2008). The anti-ghrelin Spiegelmer NOX-B11-3 blocks ghrelin- but not fasting-induced neuronal activation in the hypothalamic arcuate nucleus. J. Neuroendocrinol. 20, 85-92.

Benson, M. J., Roberts, J. P., Wingate, D. L., Rogers, J., Deeks, J. J., Castillo, F. D., and Williams, N. S. (1994). Small bowel motility following major intra-abdominal surgery: the effects of opiates and rectal cisapride. Gastroenterology 106, 924-936.

Boivin, M. A., Carey, M. C., and Levy, H. (2003). Erythromycin accelerates gastric emptying in a dose-response manner in healthy subjects. Pharmacotherapy 23, 5-8.

Bray, G. A. (2000). Afferent signals regulating food intake. Proc. Nutr. Soc. 59, 373-384.

Bresciani, E., Rapetti, D., Donà, F., Bulgarelli, I., Tamiazzo, L., Locatelli, V., and Torsello, A. (2006). Obestatin inhibits feeding but does not modu-

In this review we have focused on what happens to the stomach during hunger. It is becoming clear that phase III MMC contractions in the gastric antrum are involved in signaling feelings of hunger, pointing to a role for motilin as well as ghrelin in promoting this sensation. The absence of a functional motilin system in rodents has hampered investigations into possible roles for this hormone, but the availability of selective motilin receptor agonists suitable for human studies, now promises to open up this area of research. Finally, the post-translational processing of ghrelin, and its interactions with des-acyl-ghrelin and obestatin, reveals a complex physiology which now needs to be studied in patients with different disorders.

In terms of new drugs, the biology of the "hungry stomach" is already beginning to generate interesting investigational compounds which interact with both the motilin and the ghrelin receptors. Their progression through clinical trials is awaited with great interest.

late $\mathrm{GH}$ and corticosterone secretion in the rat. J. Endocrinol. Invest. 29, RC16-RC18.

Broad, J., Mukherjee, S., Boundouki, G., Dukes, G. E., and Sanger, G. J. (2010). Different abilities of [Nle13]-motilin and the motilin receptor agonist GSK962040 to facilitate cholinergic and nitrergic activity in human isolated stomach. Neurogastroenterol. Motil. 22, 84.

Broglio, F., Gianotti, L., Destefanis, S., Fassino, S., Abbate Daga, G., Mondelli, V., Lanfranco, F., Gottero, C., Gauna, C., Hofland, L., Van der Lely, A. J., and Ghigo, E. (2004). The endocrine response to acute ghrelin administration is blunted in patients with anorexia nervosa, a ghrelin hypersecretory state. Clin. Endocrinol. 60, 592-599.

Bülbül, M., Tan, R., Gemici, B., Ozdem, S. Ustünel, I., Acar, N., and Izgüt-Uysal, V. N. (2010). Endogenous orexin-A modulates gastric motility by peripheral mechanisms in rats. Peptides 31, 1099-1108.

Camilleri, M., Papathanasopoulos, A., and Odunsi, S. T. (2009). Action and therapeutic pathways of ghrelin for gastrointestinal disorders. Nat. Rev. Gastroenterol. Hepatol. 6, 343-352.

Carreras, C. W., Claypool, M., Santi, D. V., Schuukes, J., Peeters, T. L., and Johnson, R. G. (2004). Tachyphylaxis assays for motilin agonist drug development. Gastroenterology 126, A276.

Chapman, M., Fraser, R., Vozzo, R., Bryant, L., Tam, W., Nguyen, N., Zacharakis, B., Butler, R., Daavidson, G., and Horowitz, M. (2005). Antro-pyloroduodenal motor responses to gastric and duodenal nutrient in critically ill patients. Gut 54, 1384-1390.

Charoenthongtrakul, S., Giuliana, D., Longo, K. A., Govek, E. K., Nolan, A., Gagne, S., Morgan, K., Hixon, J.,
Flynn, N., Murphy, B. J., Hernandez, A. S., Li, J., Tino, J. A., Gordon, D. A., DiStefano, P. S., and Gedes, B. J. (2009). Enhanced gastrointestinal motility with orally active ghrelin receptor agonists. J. Pharmacol. Exp. Ther. 329, 1178-1186.

Chen, C.-Y.,Asakawa, A., Fujimya, M., Lee, S.-D., and Inui, A. (2009). Ghrelin gene products and the regulation of food intake and gut motility. Pharmacol. Rev. 61, 430-481.

Chen, C.-Y., Inui, A., Asakawa, A., Fujino, K., Kato, I., Chen, C. C., Ueno, N., and Fujimiya, M. (2005). Des-acyl ghrelin acts by CRF type 2 receptors to disrupt fasted stomach motility in conscious rats. Gastroenterology 129, 8-25.

Chung, S. A., Greenberg, G. R., and Diamant, N. E. (1995). Vagal control of fasting somatostatin levels. Neurogastroenterol. Motil. 7, 73-78.

Cline, M. A., Prall, B. C., Rogers, J. O., and Tachibana, T. (2009). Satiety induced by central stresscopin is mediated by corticotrophin-releasing factor receptors and hypothalamic changes in chicks. Pharmacol. Biochem. Behav. 92, 663-669.

Corbetta, S., Peracchi, M., Cappiello, V., Lania, A., Lauri, E., Vago, L., BeckPeccoz, P., and Spada, A. (2003). Circulating ghrelin levels in patients with pancreatic and gastrointestinal neuroendocrine tumors: identification of one pancreatic ghrelinoma. J. Clin. Endocrinol. Metab. 88, 3117-3120.

Coulie, B., Tack, J., Peeters, T., and Janssens, J. (1998). Involvement of two different pathways in the motor effects of erythromycin on the gastric antrum in humans. Gut 43, 395-400.

Cummings, D. E., Purnell, J. Q., Frayo, R. S., Schmidova, K., Wisse, B. E., and Weigle, D.S. (2001). A preprandial rise in plasma ghrelin levels suggests a role 
in meal initiation in humans. Diabetes 50, 1714-1719.

Cuomo, R., Vandaele, P., Coulie, B., Peeters, T., Depoortere, I., Janssens, J., and Tack, J. (2006). Influence of motilin on gastric fundus tone and on meal-induced satiety in man: role of cholinergic pathways. Am. J. Gastroenterol. 101, 804-811.

Dass, N. B., Hill, J., Muir, A., Testa, T., Wise, A., and Sanger, G. J. (2003a). The rabbit motilin receptor: molecular characterisation and pharmacology. $\mathrm{Br}$. J. Pharmacol. 140, 948-954.

Dass, N. B., Monunyara, M., Bassil, A. K., Hervieu, G. J., Osbourne, S., Corcoran, S., Morgan, M., and Sanger, G. J. (2003b). Growth hormone secretagogue receptors in the rat and human gastrointestinal tract and the effects of ghrelin. Neuroscience 120, 443-453.

Date, Y., Murakami, N., Toshinai, K., Matsukura, S., Niijima, A., Matsuo, H., Kangawa, K., and Nakazato, M. (2002). The role of the gastric afferent vagal nerve in ghrelin-induced feeding and growth hormone secretion in rats. Gastroenterology 123, 1120-1128.

Davenport, A. P., Bonner, T. I., Foord, S. M., Harmar, A. J., Neubig, R. R., Pin, J.-P., Spedding, M., Kojima, M., and Kangawa, K. (2005). International union of pharmacology. LVI. Ghrelin receptor nomenclature, distribution, and function. Pharmacol. Rev. 57, 541-546.

Davidson, H. I., Pilot, M.-A., and Thompson, H.H. (1990). Involvement of 5-hydroxytryptamine in canine intestinal motility patterns. J. Gastrointest. Motil. 2, 31-39.

De Smet, B., Thijs, T., Peeters, T. L., and Depoortere, I. (2007). Effect of peripheral obestatin on gastric emptying and intestinal contractility in rodents. Neurogastroenterol. Motil. 19, 211-217.

De Winter, B. Y., De Man, J. G., Seerden, T. C., Depoortere, I., Herman, A. G., Peeters, T. L., and Pelckmans, P. A. (2004). Effect of ghrelin and growth hormone-releasing peptide 6 on septic ileus in mice. Neurogastroenterol. Motil. 16, 439-446.

Depoortere, I. (2009). Targeting the ghrelin receptor to regulate food intake. Regul. Pept. 156, 13-23.

Dhir, R., and Richter, J. E. (2004). Erythromycin in the short and longterm control of dyspepsia symptoms in patients with gastroparesis. J. Clin. Gastroenterol. 38, 237-242.

Dibaise, J. K., and Quigley, E. M. (1999). Efficacy of prolonged administration of intravenous erythromycin in an ambulatory setting as treatment of severe gastroparesis: one centre's experience. J. Clin. Gastroenterol. 28, 131-134.
Dukes, G. E., Barton, M., Dewit, O., Hicks, K., Vasist, L., Van Hecken, A., De Hoon, J., Verbeke, K., Young, M., Williams, P., and Alpers, D. (2009). Pharmacokinetics, safety/tolerability, and effect on gastric emptying of the oral motilin receptor agonist, GSK962040, in healthy male and female volunteers. Neurogastroenterol. Motil. 21, 84.

Dukes, G. E., Barton, M., Dewit, O., Stephens, K., Vasist, L., Young, M., Richards, D., Alpers, D., and Williams, P. (2010). Safety/tolerability, pharmacokinetics (PK), and effect on gastric emptying (GE) with 14-days repeat oral dosing of the motilin receptor agonist, GSK962040, in healthy male and female volunteers. Neurogastroenterol. Motil. 22, 14-15.

Dun, S. L., Brailoiu, G. C., Brailoiu, E., Yang, J., Chang, J. K., and Dun, N. J. (2006). Distribution and biological activity of obestatin in the rat. J. Endocrinol. 191, 481-489.

Edholm, T., Levin, F., Hellstrom, P. M., and Schmidt, P. T. (2004). Ghrelin stimulates motility in the small intestine of rats through intrinsic cholinergic neurons. Regul. Pept. 121, 25-30.

Egerød, K. L., Holst, B., Petersen, P. S., Hansen, J. B., Mulder, J., Hökfelt, T., and Schwartz, T. W. (2007). GPR39 splice variants versus antisense gene LYPD1: expression and regulation in gastrointestinal tract, endocrine pancreas, liver, and white adipose tissues. Mol. Endocrinol. 21, 1685-1698.

Ehrström, M., Gustafsson, T., Finn, A., Kirchgessner, A., Grybäck, P., Jacobsson, H., Hellström, P. M., and Näslund, E. (2005). Inhibitory effect of exogenous orexin A on gastric emptying, plasma leptin, and the distribution of orexin and orexin receptors in the gut and pancreas in man. J. Clin. Endocrinol. Metab. 90, 2370-2377.

Esler, W. P., Rudolph, J., Claus, T.H., Tang, W., Barucci, N., Brown, S.-E., Bullock, W., Daly, M., DeCarr, L., Li, Y., Milardo, L., Molstad, D., Zhu, J., Gardell, S. J., Livingston, J. N., and Sweet, L. J. (2007). Small-molecule ghrelin receptor antagonists improve glucose tolerance, suppress appetite and promote weight loss. Endocrinology 148, 5175-5185.

Falkén, Y., Hellström, P. M., Sanger, G. J., Dewit, O., Grybäck, P., Holst, J. J., and Näslund, E. (2010). Actions of prolonged ghrelin infusion on gastrointestinal transit and glucose homeostasis in humans. Neurogastroenterol. Motil. 22, e192-e200.

Feurle, G. E., Pfeiffer, A., Schmidt, T., Dominguez-Munoz,E., Malfertheiner, P., and Hamscher, G. (2001). Phase III of the migrating motor complex: associated with endogenous xenin plasma peaks and induced by exogenous xenin. Neurogastroenterol. Motil. 13, 237-246.

Foster-Schubert, K. E., and Cummings, D. E. (2006). Emerging therapeutic strategies for obesity. Endocr. Rev. 27, 779-793.

Fraser, G. L., Hoveyda, H. R., Venkova, K. Johnson, A., Samia, M., GreenwoodVan Meerveld, B., and Tannenbaum, G. S. (2005). Pharmacological separation of gastrointestinal and endocrine effects of ghrelin using a novel ghrelin agonist, TZP-101. Neurogastroenterol. Motil. 17, 85.

Fujimiya, M., Asakawa, A., Ataka, K. Chen, C.-Y., Kato, I., and Inui, A. (2010). Ghrelin, des-acyl ghrelin, and obestatin: regulatory roles on the gastrointestinal motility. Int. J. Pept. 2010, 8.

Gill, R. C., Kellow, J. E., and Wingate, D. L. (1987). Gastro-oesophageal reflux and the migrating motor complex. Gut 28, 929-934.

Gourcerol, G., Million, M., Adelson, D. W., Wang, Y., Wang, L., Rivier, J., St-Pierre, D. H., and Taché, Y. (2006) Lack of interaction between peripheral injection of CCK and obestatin in the regulation of gastric satiety signaling in rodents, Peptides 27, 2811-2819.

Guerrero-Lindner, E., Arruebo, M. P. Murillo, M.D., and Plaza, M.A. (1996). Effect of motilin on gastrointestinal myoelectric activity in conscious rabbits. Peptides 17, 901-907.

Gutierrez, J. A., Solenberg, P. J., Perkins, D. R., Willency, J.A., Knierman, M. D. Jin, Z., Witcher, D. R., Luo, S., Onyia, J. E., and Hale, J. E. (2008). Ghrelin octanoylation mediated by an orphan lipid transferase. Proc. Natl. Acad. Sci. U.S.A. 105, 6320-6325.

Hall, K. E., Greenberg, G. R., El-Sharkawy, T. Y., and Diamant, N. E. (1984). Relationship between porcine motilin-induced migrating complex-like activity, vagal integrity and endogenous motilin release in dogs. Gastroenterology 87, 76-85.

He, J., Irwin, D. M., Chen, R., and Zhang, Y. (2010). Stepwise loss of motilin and its specific receptor genes in rodents. J. Mol. Endocrinol. 44, 37-44.

Hellström, P. M. Geliebter, A., Näslund E., Schmidt, P. T., Yahav, E. K., Hashim, S. A., and Yeomans, M. R. (2004). Peripheral and central signals in the control of eating in normal, obese and binge-eating human subjects. $B r$. J. Nutr. 92(Suppl. 1), 47-57.

Hershfinkel, M., Silverman, W. F., and Sekler, I. (2007). The zinc sensing receptor, a link between zinc and cell signalling. Mol. Med. 13, 331-336.

Holst, B., Egerød, K. L., Schild, E., Vickers, S. P., Cheetham, S., Gerlach, L.-O., Storjohann, L., Stidsen, C. E., Jones,
R., B-Sickinger, A. G., and Schwartz, T. W. (2007). GPR39 signaling is stimulated by zinc ions but not by obestatin. Endocrinology 148, 13-20.

Huda, M. S. B., Wilding, J. P. H., and Pinkney, J. H. (2006). Gut peptides and the regulation of appetite. Obes. Rev. 7, 163-182.

Husebye, E. (1999). The patterns of small bowel motility: physiology and implications in organic disease and functional disorders. Neurogastroenterol. Motil. 11, 141-161.

Inatomi, N., Sato, F., Marui, S., Itoh,Z., and Omura, S. (1996). Vagus-dependent and vagus-independent mechanisms of action of the erythromycin derivative EM574 and motilin in dogs. Jpn. J. Pharmacol. 71, 29-38.

Itoh, Z., Aizawa, S., Takeuchi, S., and Couch, E. F. (1975). "Hunger contractions and motilin," in Proceedings of the Fifth International Symposium on Gastrointestinal Motility, ed. G. Vantrappen (Herentals: Typoff Press), 48-55.

Jarvie, E. M., North Laidler, V., Corcoran, S., Bassil, A., and Sanger, G. J. (2007). Differences between the abilities of tegaserod and motilin receptor agonists to stimulate gastric motility in vitro. Br. J. Pharmacol. 150, 455-462.

Kaiya, H., Miyazato, M., Kangawa, K., Peter, R. E., and Unniappan, S. (2008). Ghrelin: a multifunctional hormone in non-mammalian vertebrates. Comp. Biochem. Physiol., Part A Mol. Integr. Physiol. 149, 109-128.

Katayama, Y., Hirai, K., Homma, T., Noda, Y., and Honda, K. (2005). Actions of orexins on individual myenteric neurons of the guinea-pig ileum: orexin A or B? Neuroreport 16, 745-749.

Kellow, J. E., Borody, T. J., Phillips, S. F., Tucker, R. L., and Haddad,A.C. (1986). Human interdigestive motility: variations in patterns from esophagus to colon. Gastroenterology 91, 386-395.

Kojima,M.,Hosoda,H., Date,Y., Nakazato, M., Matsuo, H., and Kangawa, K. (1999). Ghrelin is a growth-hormonereleasing acylated peptide from stomach. Nature 402, 656-660.

Komaki, G., Matsumoto, Y., Nishikata, H., Kawai, K., Nozaki, T., Takii, M., Sogawa, H., and Kubo, C. (2001). Orexin-A and leptin change inversely in fasting non-obese subjects. Eur. J. Endocrinol. 144, 645-651.

Kumar, R., Salehi, A., Rehfeld, J. F., Hoglund, P., Lindstrom, E., and Hakanson, R. (2010). Proghrelin peptides: desacyl ghrelin is a powerful inhibitor of acylated ghrelin, likely to impair physiological effects of acyl ghrelin but not of obestatin. A study of pancreatic polypeptide secretion from mouse islets. Regul. Pept. 164, 65-70. 
Labò, G., Bortolotti, M., Vezzadini, P., and Bonora, G. (1990). Interdigestive gastroduodenal motility and serum motilin levels in patients with idiopathic delay in gastric emptying. Gastroenterology 90, 20-26.

Lagaud, G. J., Young, A., Acena, A., Morton, M. F., Barrett, T. D., and Shankley, N. P. (2007). Obestatin reduces food intake and suppresses body weight gain in rodents. Biochem. Biophys. Res. Commun. 357, 264-269.

le Roux, C. W., Neary, N. M., Halsey, T. J., Small, C.J., Martinez-Isla,A.M., Ghatei, M.A., Theodorou, N.A., and Bloom, S. R. (2005). Ghrelin does not stimulate food intake in patients with surgical procedures involving vagotomy.J. Clin. Endocrinol. Metab. 90, 4521-4524.

Lear, P. V., Iglesias, M. J., Feijóo-Bandin, S., Rodriguez-Penas, D., Mosquera-Leal, A., Garcia-Rua, V., Gualilo, O., Ghè, C., Arnoletti,E., Muccioli, G., Diéguez, C., Gonzélez-Juanatey, J. R., and Lago, F. (2010). Des-acyl ghrelin has specific binding sites and different metabolic effects from ghrelin cardiomyocytes. Endocrinology 151, 3286-3298.

Lee, K. Y., Chang, T. M., and Chey, W. Y. (1983). Effect of rabbit antimotilin serum on myoelectric activity and plasma motilin concentration in fasting dog. Am. J. Physiol. 245, G547-G553.

Leite-Moreira, A. F., and Soares, J.-B. (2007). Physiological, pathophysiological and potential therapeutic roles of ghrelin. Drug Discov. Today 12, 276-288.

Levin, F., Edholm, T., Schmidt, P. T., Grybäck, P., Jacobsson, H., Degerblad, M., Höybye, C., Holst, J. J., Rehfeld, J. F., Hellström, P. M., and Näslund, E. (2006). Ghrelin stimulates gastric emptying and hunger in normalweight humans J. Clin. Endocrinol. Metab. 91, 3296-3302.

Liu, J., Prudom, C. E., Nass, R., Pezzoli, S. S., Oliveri, M. C., Johnson, M. L., Veldhuis, P., Gordon, D. A., Howard, A. D., Witcher, D. R., Geysen, H. M., Gaylinn, B. D., and Thorner, M. O. (2008). Novel ghrelin assays provide evidence for independent regulation of ghrelin acylation and secretion in healthy young men. J. Clin. Endocrinol. Metab. 93, 1980-1987.

Liu, Y.-L., Malik, N., Sanger, G. J., and Andrews, P. L. (2006). Ghrelin alleviates cancer chemotherapy-associated dyspepsia in mice. Cancer Chemother. Pharmacol. 58, 326-333.

Matsuura, B., Dong, M., Naik, S., Miller, L. J., and Onji, M. (2006). Differential contributions of motilin receptor extracellular domains for peptide and non-peptidyl agonist binding and activity. J. Biol. Chem. 281, 12390-12396.
McCallum, R. W., Cynshi, O., US Investigative Team. (2007). Efficacy of mitemcinal, a motilin agonist, on gastrointestinal symptoms in patients with symptoms suggesting diabeticgastropathy: a randomized, multicenter, placebo-controlled trial. Aliment. Pharmacol. Ther. 26, 107-116.

Medhus, A. W., Sandstad, O., Naslund, E., Hellstrom, P. M., and Husebye, E. (1999). The influence of the migrating motor complex on the postprandial endocrine response. Scand. J. Gastroenterol. 34, 1012-1018.

Mochiki,E., Inui, A., Satoh, M., Mizumoto, A., and Itoh, Z. (1997). Motilin is a biosignal controlling cyclic release of pancreatic polypeptide via the vagus in fasted dogs. Am. J. Physiol. 272, G224-G232.

Moechars, D., Depoortere, I., Moreaux, B., de Smet, B., Goris, I., Hoskens, L., Daneels, G., Kass, S., Ver Donck, L., Peeters, T., and Coulie, B. (2006). Altered gastrointestinal and metabolic function in the GPR39-obestatin receptor knockout mouse. Gastroenterology 131, 1131-1141.

Moulin, A., Ryan, J., Martinez, J., and Fehrentz, J.-A. (2007). Recent developments in ghrelin receptor ligands. ChemMedChem 2, 1242-1259.

Murphy, K. G., and Bloom,S.R. (2006). Gut peptides and the regulation of energy homeostasis. Nature 444, 854-859.

Nagaya, N., Uematsu, M., Kojima, M., Ikeda, Y., Yoshihara, F., Shimizu, W., Hosoda, H., Hirota, Y., Ishida, H., Mori, H., and Kangawa, K. (2001). Chronic administration of ghrelin improves left ventricular dysfunction and attenuates development of cardiac cachexia in rats with heart failure. Circulation 104, 1430-1435.

Nakabayashi, M., Suzuki, T., Takahashi, K., Totsune, K., Muramatsu, Y., Kaneko, C., Date, F., Takeyama, J., Darnel, A. D., Moriya, T., and Sasano, H. (2003). Orexin-A expression in human peripheral tissues. Mol. Cell. Endocrinol. 205, 43-50.

Nakai, Y., Hosoda, H., Nin, K., Ooya, C., Hayashi,H.,Akamizu, T., and Kangawa, K. (2003). Plasma levels of active form of ghrelin during oral glucose tolerance test in patients with anorexia nervosa. Eur. J. Endocrinol. 149, R1-R3.

Nakajima, H., Mochiki, E., Zietlow, A., Ludwig, K., and Takahashi, T. (2010). Mechanism of interdigestive migrating motor complex in conscious dogs. J. Gastroenterol. 45, 506-514.

Näslund, E., Backman, L., Theodorsson, E., and Hellström, P. M. (1998). Intraduodenal neuropeptide levels, but not plasma levels, vary in a cyclic fashion with the migrating motor complex. Acta Physiol. Scand. 164, 317-323.
Näslund, E., Ehrström, M., Ma, J., Hellström, P. M., and Kirchgessner A. L. (2002). Localization and effects of orexin on fasting motility in the rat duodenum. Am. J. Physiol. 282, G470-G479.

Näslund, E., and Hellström, P. M. (2007). Appetite signaling: from gut peptides and enteric nerves to brain. Physiol. Behav. 92, 256-262.

Neary, N. M., Small, C. J., Wren, A. M., Lee, J.L., Druce, M. R., Palmieri, C., Frost, G. S., Ghatei, M. A., Coombes, R. C., and Bloom, S. R. (2004). Ghrelin increases energy intake in cancer patients with impaired appetite: acute, randomized, placebo-controlled trial. J. Clin. Endocrinol. Metab. 89, 2832-2836.

Nguyen,N.,Fraser,R.J., Bryant,L., Burgstad, C. M., Chapman, M., Clarke, S., and Holloway, R. H. (2010). Abnormalities in plasma motilin response to small intestinal nutrient stimulation in critically ill patients. Gastroenterology 138(Suppl. 1), S405-S406.

Nieuwenhuijs, V. B., Verheem, A., van Duijvenbode-Beumer, H., Visser, M. R., Verhoef, J., Gooszen, H. G., and Akkermans, L. M. (1998). The role of interdigestive small bowel motility in the regulation of gut microflora, bacterial overgrowth, and bacterial translocation in rats. Ann. Surg. 228, 188-193.

Nishizawa, T., Suzuki, H., Nomoto, Y., Masaoka, T., Hosoda, H., Mori, M. Ohara, T., Morishita, T., Kangawa, K., and Hibi, T. (2006). Enhanced plasma ghrelin levels in patients with functional dyspepsia. Aliment. Pharmacol. Ther. 24(Suppl. 4), 104-110.

Nogueiras, R., and Tschöp, M. (2005). Biomedicine. Separation of conjoined hormones yields appetite rivals. Science 310, 985-986.

Otto,B.,Cuntz,U.,Fruehauf,E., Wawarta, R. Folwaczny, C., Riepl, R. L., Heiman, M. L., Lehnert, P., Fichter, M., and Tschöp M. (2001). Weight gain decreases elevated plasma ghrelin concentrations of patients with anorexia nervosa. Eur. J. Endocrinol. 145, 669-673.

Ozaki, K., Onoma, M., Muramatsu, H., Sudo, H., Yoshida, S., Shiokawa, R., Yogo, K., Kamei, K., Cynshi, O., Kuromaru, O., Peeters, T. L., and Takanashi, H. (2009). An orally active motilin receptor antagonist, MA-2029, inhibits motilin-induced gastrointestinal motility, increase in fundic tone, and diarrhea in conscious dogs without affecting gastric emptying. Eur. J. Pharmacol. 615, 185-192.

Page, A. J., Slattery, J. A., Milte, C., Laker, R., O'Donnell, T., Dorian, C., Brierley, S. M., and Blackshaw, L. A. (2007). Ghrelin selectively reduces mechanosensitivity of upper gastrointestinal vagal afferents. Am. J. Physiol. 292, G1376-G1384.
Peeters, T. L. (1993). Erythromycin and other macrolides as prokinetic agents. Gastroenterology 105, 1886-1899.

Peeters, T. L., Janssens, J., and Vantrappen, G. R. (1983). Somatostatin and the interdigestive migrating motor complex in man. Regul. Pept. 5, 209-217.

Popescu, I., Fleshner,P., Pezzullo, J., Charlon, P., Kosutic, G., and Senagore, A. (2009). The ghrelin agonist TZP-101 for management of postoperative ileus after partial colectomy: a randomized, doseranging, placebo-controlled clinical trial. Dis. Colon Rectum 53, 126-134.

Raun, K., Hansen, B. S., Johansen, N. L., Thogersen, H., Madsen, K., Ankersen, M., and Andersen, P. H. (1998). Ipamorelin, the first selective growth hormone secretagogue. Eur. J. Endocrinol. 139, 552-561.

Read, N. W. (1992). Role of gastrointestinal factors in hunger and satiety in man. Proc. Nutr. Soc. 51, 7-11.

Rees, W.D.W., Malagelada, J.R., Miller,L. J. and Go, V.L.W. (1982). Human interdigestive and postprandial gastrointestinal motor and gastrointestinal hormone patterns. Dig. Dis. Sci. 27, 321-329.

Richards, R. D., Davenport, K., and Mccallum, R. W. (1993). The treatment of idiopathic and diabetic gastroparesis with acute intravenous and chronic oral erythromycin. Am. J. Gastroenterol. 88, 203-207.

Rolls, E. T. (1981). Central nervous mechanisms related to feeding and appetite. Br. Med. Bull. 37, 131-134.

Ruckebusch, Y., Pairet, M., and Becht, J. L. (1985). Origin and characterization of migrating myoelectric complex in rabbits. Dig. Dis. Sci. 30, 742-748.

Rudd, J. A., Ngan, M. P., Wai, M. K., King, A. G., Witherington, J., Andrews, P. L. R., and Sanger, G. J. (2006). Anti-emetic activity of ghrelin in ferrets exposed to the cytotoxic anti-cancer agent cisplatin. Neurosci. Lett. 392, 79-83.

Sakata, I., Yamazaki, M., Inoue, K., Hayashi, Y., Kangawa, K., and Sakai, T. (2003). Growth hormone secretagogue receptor expression in the cells of the stomach-projected afferent nerve in the rat nodose ganglion. Neurosci. Lett. 342, 183-186.

Samson, W. K., White, M. M., Price, C., and Ferguson, A. V. (2007). Obestatin acts in brain to inhibit thirst. Am. J. Physiol. 292, R637-R643.

Sanger, G. J. (2008). Motilin, ghrelin and related neuropeptides as targets for the treatment of GI diseases. Drug Discov. Today 13, 234-239.

Sanger, G. J., and Alpers, D. (2008). Development of drugsforgastrointestinal motor disorders: translating science to clinical need. Neurogastroenterol. Motil. 20, 177-184.

Sanger, G. J., and Lee, K. (2008). Hormones of the gut-brain axis as targets for the 
treatment of upper GI disorders. Nat. Rev. Drug Discov. 7, 241-254.

Sanger, G. J., Westaway, S. M., Barnes, A. A., MacPherson, D. T., Muir, A. I., Jarvie, E. M., Bolton, V., Cellek, S., Näslund, E., Hellström, P. M., Borman, R. A., Unsworth, W. P., Matthews, K. L., and Lee, K. (2009). GSK962040: a small molecule, selective motilin receptor agonist, effective as a stimulant of human and rabbit gastrointestinal motility. Neurogastroenterol. Motil. 21, 657-666.

Sarna, S. K. (1985). Cyclic motor activity; migrating motor complex: 1985. Gastroenterology 89, 894-913.

Scott, V., McDade, D. M., and Luckman, S. M. (2007). Rapid changes in the sensitivity of arcuate nucleus neurons to central ghrelin in relation to feeding status. Physiol. Behav. 90, 180-185.

Seoane, L. M., Al-Massadi, O., Pazos, Y., Pagotto, U., and Casanueva, F.F. (2006). Central obestatin administration does not modify either spontaneous or ghrelin-induced food intake in rats. $J$. Endocrinol. Invest. 29, RC13-RC15.

Sharir,H.,Zinger,A., Nevo,A.,Sekler, I., and Hershfinkel, M. (2010). Zn2 + released from injured cells is acting via the $\mathrm{Zn} 2+$ - sensing receptor, $\mathrm{ZnR}$, to trigger signalling leading to epithelial repair. J. Biol. Chem. 285, 26097-26106.

Shibata, C., Naito, H., Ueno, T., Jin, X. X.-L., Funayama, Y., Fukushima, K., Matsuno, S., and Sasaki, I. (2002). Intraduodenal capsaicin inhibits gastric migrating motor complex via an extrinsic neural reflex in conscious dogs. Neurogastroenterol. Motil. 14, 543-551.

Sibilia,V., Bresciani,E.,Lattuada, N., Rapetti, D., Locatelli, V., De Luca, V., Donà, F., Netti, C., Torsello, A., and Guidobono, F. (2006). Intracerebroventricular acute and chronic administration of obestatin minimally affect food intake but not weight gain in the rat.J. Endocrinol. Invest. 29, RC31-RC34.

Sudo, H., Yoshida, S., Ozaki, K., Muramatsu, H., Onoma, M., Yogo, K., Kamei, K., Cynshi, O., Kuromaru, O., Peeters, T. L., and Takanashi, H. (2008). Oral administration of MA-2029, a novel selective and competitive motilin receptor antagonist, inhibits motilin-induced intestinal contractions and visceral pain in rabbits. Eur. J. Pharmacol. 581, 296-305.

Suzuki, H., Mochiki, E., Haga, N., Satoh, M., Mizumoto, A., and Itoh, Z. (1998). Motilin controls cyclic release of insulin through vagal cholinergic muscarinic pathways in fasted dogs. Am. J. Physiol. 274, G87-G95.

Szurszewski, J. H. (1969). A migrating electric complex of the canine small intestine. Am. J. Physiol. 217, 1757-1763.

Tack, J., Depoortere, I., Bisschops, R., Delporte, C., Coulie, B., Meulemans, A., and Janssens, J. (2006). Influence of ghrelin on interdigestive gastrointestinal motility in humans. Gut 55, 327-333.

Takanashi, H., and Cynshi, O. (2009). Motilides: a long and winding road: lessons from mitemcinal (GM-611) on diabetic gastroparesis. Regul. Pept. 155, 18-23.

Takahashi, N., Koba, N., Yamamoto, T., and Sudo, M. (2010). Characterisation of a novel, potent and selective small molecule motilin receptor agonist, RQ-00201894. Gastroenterology 138(Suppl. 1), S-713.

Tanaka, M., Naruo, T., Muranaga, T., Yasuhara, D., Shiiya, T., Nakazato, M., Matsukura, S., and Nozoe, S.-I. (2002). Increased fasting plasma ghrelin levels in patients with bulimia nervosa. Eur. J. Endocrinol. 146, R1-R3.

Tanaka, T., Kendrick, M. L., Zyromski, N. J., Meile, T., and Sarr, M. G. (2001). Vagal innervations modulates motor pattern but not initiation of canine gastric migrating motor complex. Am. J. Physiol. 281, G283-G292.

Thollander, M., Hellström, P. M., Svensson, T. H., and Gazelius, B. (1996). Haemodynamic changes in the small intestine correlate to migrating motor complex in humans. Eur. J. Gastroenterol. Hepatol. 8, 777-785.

Thomas, H., Chen, C., and Marsault, E. (2007). The motilin receptor antagonist TZP-201 is highly effective in the control of irinotecan induced diarrhea in beagle dogs. Neurogastroenterol. Motil. 19(Suppl. 3), 35.

Tomita, R. (2009). Relationship between interdigestive migrating motor complex and gut hormones in human. Hepatogastroenterology 56, 714-717.

Tomita, R., Fujisaki, S., Tanjoh, K., and Fukuzawa, M. (2003). Relationship between jejuna interdigestive migrating motor complex and quality of life after total gastrectomy with Rouxxen-Y reconstruction for early gastric cancer. World J. Surg. 27, 159-163.

Toshinai, K., Yamaguchi, H., Sun, Y., Smith, R. G., Yamanaka, A., Sakurai, T., Date, Y., Mondal, M. S., Shimbara, T., Kawagoe, T., Murakami, N., Miyazato, M., Kangawa, K., and Nakazato, M. (2006). Des-Acyl ghrelin induces food intake by a mechanism independent of the growth hormone secretagogue receptor. Endocrinology 147, 2306-2314.

Tremblay, F., Perreault, M., Klaman, L. D., Tobin, J. F., Smith, E., and Gimeno, R. E. (2007). Normal food intake and body weight in mice lacking the $\mathrm{G}$ protein-coupled receptor GPR39. Endocrinology 148, 501-506.

Tremblay, F., Richard, A.-M. T., Will, S., Syed, J., Stedman, N., Perreault, M., and Gimeno, R. E. (2009). Disruption of $\mathrm{G}$ protein-coupled receptor 39 impairs insulin secretion in vivo. Endocrinology 150, 2586-2595.
Trudel,L., Bouin,M., Tomasetto, C., Eberling, P., St-Pierre, S., Bannon, P., L'Heureux, M. C., and Poitras, P. (2003). Two new peptides to improve postoperative gastric ileus in dog. Peptides 24, 531-534.

Vantrappen, G., Janssens, J., Hellemans, J., and Ghoos, Y. (1977). The interdigestive motor complex of normal subjects and patients with bacterial overgrowth of the small intestine. J. Clin. Invest. 59, 1158-1166.

Venkova, K., Thomas, H., Fraser, G. L., and Greenwood-Van Meerveld, B. (2009a). Effect of TZP-201, a novel motilin receptor antagonist, in the colon of the musk shrew (Suncus murinus). J. Pharm. Pharmacol. 61, 367-373.

Venkova, K., Mann, W., Nelson, R., and Greenwood-Van Meerveld, B. (2009b) Efficacy of ipamorelin, a novel ghrelin mimetic, in a rodent model of postoperative ileus. J. Pharmacol. Exp. Ther. 329, 1110-1116.

Vestergaard,E.T.Hansen, T.K., Gormsen, L. C., Jakobsen,P., Moller, N., Christiansen, J. S., and Jorgensen, J. O. L. (2007). Constant intravenous ghrelin infusion in healthy young men: clinical pharmacokinetics and metabolic effects. Am. J. Physiol. 292, E1829-E1836.

Von der Ohe, M. R., Camilleri, M., Thomforde, G. M., and Klee, G. G. (1995). Differential effects of octreotide on human gastrointestinal motor function. Gut 36, 743-748.

Westaway, S. M., and Sanger, G. J. (2009). The identification and rationale for drugs which act at the motilin receptor. Prog. Med. Chem. 48, 31-80. (ed. G. Lawton and D. Witty).

Wigglesworth, M., Wolfe, L.A., and Wise,A. (2006). Orphan seven transmembrane receptor screening. Ernst. Schering Found Symp. Proc. 2, 105-143.

Williams, D. L., and Cummings, D. E. (2005). Regulation of ghrelin in physiologic and pathophysiologic states. J. Nutr. 135, 1320-1325.

Wilmer, A., Tack, J., Coremans, G., Janssens, J., Peeters, T., and Vantrappen, G. (1993). 5-Hydroxytryptamine 3 receptors are involved in the initiation of gastric phase 3 motor activity. Gastroenterology 105, 773-778.

Wo, J., Malik, R., Nowak, T., Snape, W., Hellström, P. M., Shaughnessy, L., Kosutic, G., and McCallum, R. (2010). TZP-101 (ghrelin agonist) effects on daily vomiting due to diabetic gastroparesis (GP): phase 2 subset analysis. Neurogastroenterol. Motil. 22, 13-14.

Yamamoto, I., Kimura, N., Arai, T., and Tanaka, M. (2009).cDNA cloning and mRNA expression of boving GPR39. J. Vet. Med. Sci. 71, 641-644.

Yang, J., Brown, M. S., Liang, G., Grishin, N. V., and Goldstein, J. L. (2008), Identification of the acyltransferase that octanoylates ghrelin, an appetite-stimulating peptide hormone. Cell 132, 387-396.

Yoshida, N., Mizumotor, A., Iowanaga, Y., and Itoh, Z. (1991). Effects of 5-hydroxytryptamine 3 receptor antagonists on gastrointestinal motor activity in conscious dogs. J. Phamacol. Exp. Ther. 256, 272-278.

Yoshiya, K., Yamamura, T., Ishikawa, Y., Utsunomiya,J.,Mori, K.,Seino,Y.,Imura, H., and Yanaihara, N. (1985). The failure of truncal vagotomy to affect motilin release in dogs. J. Surg. Res. 38, 263-266.

Zhang, J. V., Klein, C., Ren, P.-G., Kass, S., Donck, L.V., Moechars, D., and Hsueh, A. J.W. (2007). Response to comment on "obestatin, a peptide encoded by the ghrelin gene, opposes ghrelin's effects on food intake." Science 315, 766.

Zhang,J.V., Ren, P.-G., Avsian-Kretchmer, O., Luo, C.-W., Rauch, R., Klein, C., and Hsueh, A. J. W. (2005). Obestatin, a peptide encoded by the ghrelin gene, opposes ghrelin's effects on food intake. Science 310, 996-986.

Zhou, S., Chan, E., Lim, L. Y., Boelsterli, U. A., Li, S.C., Wang, J., Zhang, Q., Huang, M., and Xu, A. (2004). Therapeutic drugs that behave as mechanism-based inhibitors of cytochrome P450 3A4. Curr. Drug Metab. 5, 415-442.

Zietlow, A. M., Ludwig, K. A., and Takahashi, T. (2010). Association between plasma ghrelin and motilin levels during $\mathrm{MMC}$ cycle in conscious dogs. Regul. Pept. 164, 78-82.

Zorrilla,E.P., Iwasaki,S., Moss, J.A., Chang, J., Otsuji, J., Inoue, K., Meijer, M. M., and Janda, K. D. (2006). Vaccination against weight gain. Proc. Natl. Acad. Sci. U.S.A. 103, 13226-13231.

Conflict of Interest Statement: Gareth $\mathrm{J}$. Sanger is the recipient of a grant from GlaxoSmithKline to study the mechanisms of action of motilin receptor agonists. Per M. Hellström is an unpaid member of the Tranzyme Pharma scientific board. Erik Näslund has nothing to disclose.

Received: 23 September 2010; paper pending published: 18 November 2010; accepted: 22 December 2010; published online: 18 February 2011.

Citation: Sanger GJ, Hellström PM and Näslund E (2011) The hungry stomach: physiology, disease, and drug development opportunities. Front. Pharmacol. 1:145. doi: 10.3389/fphar.2010.00145

This article was submitted to Frontiers in Gastrointestinal Pharmacology, a specialty of Frontiers in Pharmacology.

Copyright (c) 2011 Sanger, Hellström and Näslund. This is an open-access article subject to an exclusive license agreement between the authors and Frontiers Media SA, which permits unrestricted use, distribution, and reproduction in any medium, provided the original authors and source are credited. 